\title{
Inga pitmanii (Fabaceae), a New Species from Madre de Dios, Peru
}

\author{
Kyle G. Dexter \\ Laboratoire Evolution et Diversité Biologique, UMR 5174, CNRS/Université Paul Sabatier, \\ Bâtiment 4R3, 31062, Toulouse, France. Author for correspondence: kgdexter@gmail.com
}

Terence D. Pennington

Royal Botanic Gardens Kew, Richmond TW9 3AB, Surrey, United Kingdom

Abstract. Inga pitmanii K. G. Dexter \& T. D. Penn., a new species of Inga Mill. from Madre de Dios, Peru, is described for the Fabaceae (Mimosoideae). Morphologically it is closest to I. chartacea Poepp. \& Endl., with which it shares a broadly winged rhachis, spicate inflorescence, glabrous leaves, nine to 10 pairs of secondary veins, and similar calyx indumentum. Inga pitmanii differs from I. chartacea in the leaflet number (four pairs vs. usually two or three pairs), the foliar nectaries (cyathiform vs. patelliform), and the larger flowers (with corollas 9-11.5 mm vs. 4.5-7 mm). Phylogenetic analyses show this species belongs to a clade including I. acreana Harms and I. chartacea. This species was discovered during field surveys for an ecological study of the genus Inga at the Los Amigos Biological Station in Madre de Dios, Peru. These field surveys uncovered several potentially novel species of the genus Inga, none of which matched any known species based on vegetative characters and the majority of which are genetically distinct. Here we describe $I$. pitmanii as this is the only species that was collected in a fertile state. Given current and future limitations in taxonomic expertise and funding, we advocate consideration of nonconventional approaches to species discovery, such as combining biodiversity surveys with large-scale DNA sequencing. This would in turn allow ecologists, who often collect plants in poorly known regions, to make a greater contribution to the species-discovery process.

Resumen. Inga pitmanï K. G. Dexter \& T. D. Penn. es descrita como una nueva especie del género Inga Mill. de Madre de Dios, Perú. Morfológicamente es más similar a I. chartacea Poepp. \& Endl., con alas anchas en el rachis, inflorescencia espigada, hojas glabras, nueve a 10 nervios secundarios e indumento parecido en el cáliz. Inga pitmanii se diferencia de $I$. chartacea por el número de folíolos (cuatro pares vs. dos hasta tres), los nectarios foliares (ciatiformes vs. pateliformes), y las flores más grandes (corola 9-11.5 $\mathrm{mm}$ vs. $4.5-7 \mathrm{~mm})$. La especie fue descubierta durante los censos hechos para un estudio ecológico del género Inga. Análisis filogenéticos muestran que esta especie forma parte de un grupo que incluye a $I$. acreana Harms e I. chartacea. Esta especia fue descubierta en censos de campo para un estudio ecológico del género en la Estación Biológica Los Amigos, en Madre de Dios, Perú. Estos censos descubrieron algunas especies de Inga potencialmente nuevas, que no coinciden en sus características vegetativas con ninguna de las especies de Inga conocidas hasta ahora. Además, la mayoría de estas especies demostraron ser distintas genéticamente. Aquí se describe únicamente $I$. pitmanii, porque es la única especie que se ha encontrado en estado fértil. Debido a las limitaciones que tanto la competencia como el financiamiento imponen a la taxonomía hoy en día, y éstas aunadas a la convención de describir especies nuevas solo y únicamente sí son fértiles, sugerimos que deberían considerarse métodos alternativos para descubrir nuevas especies, tales como la combinación de censos de biodiversidad y las secuencias de ADN en una escala mayor. Esto, a su vez permitirá a los ecólogos que frecuentemente recolectan plantas en regiones poco conocidas, contribuir al descubrimiento de nuevas especies.

Key words: Fabaceae, Inga, IUCN Red List, lowland Amazon, Madre de Dios, Peru.

Inga Mill. (Fabaceae: Mimosoideae) is a characteristic tree genus of Neotropical rainforests with a distribution extending from northwestern Mexico to Uruguay. The genus currently comprises more than 250 named species (Pennington, 1997). Despite being ecologically important, abundant, and frequently collected, it is estimated that there may be 50 or more imperfectly known or undescribed species in the genus (Pennington, 1997).

The Madre de Dios Department, in southeastern Peru, consists almost entirely of lowland, Amazonian rainforest. While there is limited human impact associated with several towns, roads, and extractive activities (gold mining, logging), the rainforests of the 
department are in largely pristine condition. The two principal habitat types in the department are upland terra firme forest and bottomland floodplain forest (Terborgh, 1990; Pitman et al., 1999). Minor habitat types include permanently inundated areas such as Mauritia flexuosa L. f. palm swamps (aguajales) and Ficus trigona L. f.-dominated swamps (renacales). Also, much of the forest in terra firme is dominated by woody bamboo species, principally Guadua Kunth.

We undertook an ecological study of the distribution and dispersal of Inga across environmental gradients in Madre de Dios (Dexter, 2008; Dexter et al., 2010). As part of this study, we made extensive collections of Inga individuals, which were generally sterile, in order to identify and delimit species (Dexter et al., 2010). After comparison with the extensive collections of Inga at Kew and several U.S. herbaria (DUKE, MO, NY, US), an estimated 10 of our morphospecies were unassignable to known species. One of these morphospecies was collected in a fertile state and is described herein.

Inga pitmanii K. G. Dexter \& T. D. Penn., sp. nov. TYPE: Peru. Madre de Dios: Los Amigos Biol. Station, Rio Los Amigos, $12^{\circ} 34^{\prime} \mathrm{S}, 70^{\circ} 05^{\prime} \mathrm{W}, 8$ June 2004 (fl.), K. Dexter \& F. Parra 336 (holotype, K; isotype, DUKE). Figure 1.

Haec species Ingae chartaceae Poepp. affinis, sed ab ea foliolis 4-jugis, nectariis foliaribus brevistipitatis cyathiformibus, foliolorum nervibus secundariis paucioribus utrinque elevatis, pedunculo longiore et floribus majoribus differt.

Tree 25-35 cm DBH with tan-gray, lenticellate, smooth bark, slash orange, exuding a clear yellow exudate; young shoots angular, pale lenticellate, grayish brown, initially sparsely and minutely appressed puberulent, becoming glabrate. Stipules $1-1.5 \times 0.1-0.15 \mathrm{~cm}$, linear to falcate, subglabrous, caducous; petiole $4.5-5.5 \mathrm{~cm}$, winged portion 4-6 $\mathrm{mm}$ wide, glabrous; rhachis $14.6-18.5 \mathrm{~cm}$, winged portion $0.6-1.1 \mathrm{~cm}$ wide, glabrous, appendix ca. 1.2 $\mathrm{cm}$, or absent; foliar nectaries shortly stalked $(\leq 1$ $\mathrm{mm}$ ), cyathiform, ca. $2 \mathrm{~mm}$ diam.; petiolule $3-4 \mathrm{~mm}$, glabrous; leaflets in 4 pairs, the terminal pair 19$25.5 \times 7.6-9 \mathrm{~cm}$, elliptic to oblong-elliptic, apex short to long acuminate, base rounded and finally slightly cordate, slightly asymmetrical; basal pair 10$11.2 \times 4.5-5.1 \mathrm{~cm}$, elliptic, apex acuminate, base truncate to slightly cordate; glabrous; venation eucamptodromous, secondary veins in 9 or 10 pairs, ascending, arcuate and convergent, raised on both surfaces when dry, intersecondary veins present, extending about halfway to the margin, tertiary veins mostly oblique and parallel. Inflorescence axillary, solitary, a strongly congested spike; peduncle ca. 6 $\mathrm{cm}$, slender, glabrous; fertile rhachis $2-3 \mathrm{~mm}$; bracts $2-3 \mathrm{~mm}$, spatulate, sparsely puberulent, persistent; pedicel $0.5-1 \mathrm{~mm}$, puberulent. Flowers with a whitish appearance to the corolla and stamens; calyx tube 6-7 mm, slightly expanded from base to apex; lobes $0.5-1 \mathrm{~mm}$, triangular, acute at apex, calyx sparsely puberulent, more densely puberulent on the lobes; corolla tube $8-10 \mathrm{~mm}$, lobes 1-1.5 mm, triangular, acute at apex, densely and coarsely pubescent outside; stamens ca. 50 , staminal tube $1.1-1.4 \mathrm{~cm}, 0.5-0.75 \mathrm{~mm}$ diam., finally exserted $1-2$ $\mathrm{mm}$, free filaments $1-1.2 \mathrm{~cm}$; ovary of 1 carpel, glabrous, style equaling the stamens, style head capitate; ovules ca. 16. Legume unknown.

Distribution and ecology. At present the species is known with certainty only from the type collection in Madre de Dios, Peru, which was the only fertile collection seen by the authors. There Inga pitmanii occurs in primary forest on nonflooded terraces with sandy soil. Additional sterile collections are from both nonflooded terraces with sandy soil and seasonally flooded terraces with clayey soil and are cited as paratypes.

IUCN Red List category. As of now, we recommend that this species be classified as Least Concern (LC), according to IUCN Red List criteria (IUCN, 2001). Although the species is locally rare, it appears to be present across Madre de Dios, and the rainforest habitat of the species is fairly intact. If the forests of Madre de Dios face extensive clearance in the future, the status of the species should be reevaluated, because it is not currently known from any other locations.

Phenology. Flowering occurs at the beginning of the dry season in June.

Etymology. This species is named in honor of Nigel Pitman for his dedicated efforts to advance Peruvian research capacity while research director of the Los Amigos Biological Station, where the type specimen was collected. Furthermore, the type specimen was collected when Nigel Pitman was teaching the first author of this article how to climb and collect tree materials. The type specimen was in fact the first Inga ever collected by the first author, whose dissertation research focused largely on Inga.

Discussion. Inga pitmanii is assigned to section Pseudinga Benth. on the basis of its short stalked foliar nectary, congested spike inflorescence, and calyx and corolla length. The diagnostic characters of the species are the large glabrous leaves with winged rachi, long petioles, congested inflorescences on long 


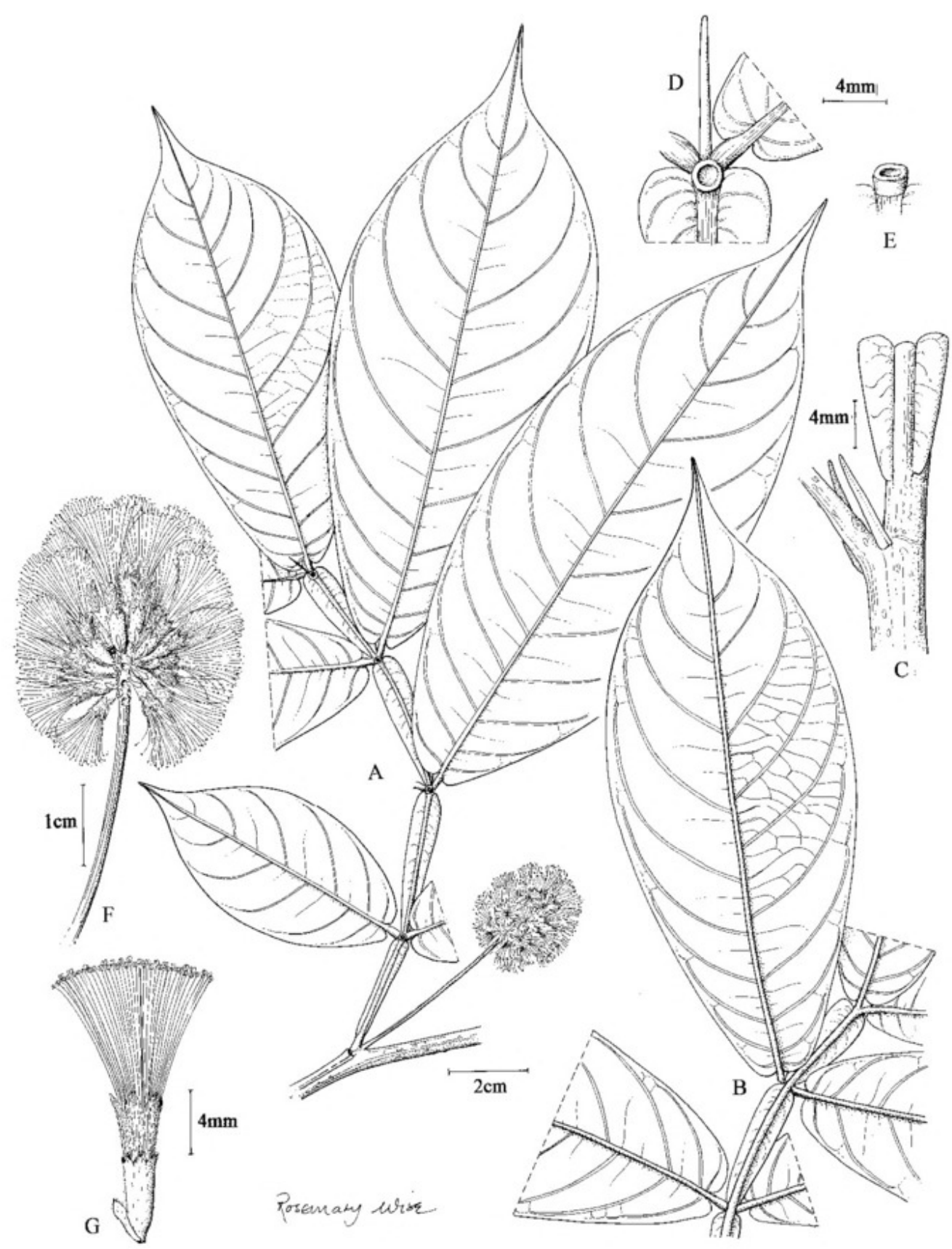

Figure 1. Inga pitmanii K. G. Dexter \& T. D. Penn. -A. Fertile habit. - B. Leaf, abaxial surface. - C. Leaf axil and stipule. -D. Foliar nectary, adaxial view. - E. Foliar nectary, lateral view. - F. Inflorescence. —G. Individual flower. Drawn from the holotype Dexter \& Parra 336 (K).

peduncles, and small, densely pubescent corollas. These characters indicate that the new taxon is most closely related to $I$. chartacea Poepp. \& Endl., also in section Pseudinga, and it keys out at that species in a recent monograph of Inga (Pennington, 1997). However, there are several significant differences in both vegetative and floral morphology between the new species and $I$. chartacea. Leaflets are in four pairs in I. pitmanii (vs. two or three pairs in $I$. chartacea); foliar nectaries are shortly stalked and cyathiform (vs. sessile and patelliform); and the secondary veins are in nine to 10 pairs, raised on both surfaces (vs. 11 to 13 pairs and usually impressed adaxially). Furthermore, the fertile peduncles are longer in I. pitmanii (ca. $6 \mathrm{~cm}$ vs. $0.8-3 \mathrm{~cm}$ in I. chartacea); the flowers are larger, with the calyx tube 6-7 mm long (vs. 1.75-2.5 mm); the corolla tube is $8-10 \mathrm{~mm}$ long (vs. $3.5-5.5 \mathrm{~mm}$ ); the staminal tube is 1.1-1.4 cm long (vs. 5.5-6.5 mm); and the free filaments are $1-1.2 \mathrm{~cm}$ long (vs. 6-7 mm).

As part of a previous study, we conducted exhaustive maximum likelihood and Bayesian phylogenetic analyses of Inga species in Madre de Dios, Peru, based on sequences of the nuclear ITS and chloroplast trnD-T markers (Dexter et al., 2010). This placed the new species (labeled in Dexter et al., 
2010, as Inga morphospecies 49) as sister to a clade that includes I. acreana Harms and I. chartacea with moderately strong posterior probability support. The phylogenetic analyses suggest that all sequenced specimens of I. pitmanii form a monophyletic clade, although there is not strong support for this hypothesis. Further sequencing efforts are needed to definitively confirm that the species forms a monophyletic clade and that its closest relatives are $I$. acreana and $I$. chartacea. We note that this phylogenetic analysis only included species from Madre de Dios; thus, it is possible that an unsampled species outside of this study area may actually be more closely related to $I$. pitmanii.

Inga pitmanii is one of 10 morphospecies of Inga that we uncovered in our ecological surveys in Madre de Dios and to which we were not able to assign a taxonomic name (Dexter et al., 2010). The other morphospecies are only represented by sterile collections. Convention dictates that they remain unnamed until fertile collections are found. However, each of these species is vegetatively distinct from all other Inga species known to date from the Amazon basin, and in most cases, also genetically distinct from all co-occurring species (Dexter et al., 2010). This suggests the species are likely new to science.

Ecologists, particularly tropical ecologists, frequently encounter sterile plants (or other organisms) to which they are not able to definitively assign a species name. While many of these individuals may belong to previously described species, many of them may also represent novel species. The status of these individuals as novel species can be assessed by comparing their DNA sequences to a large database of sequences from closely related, taxonomically identified individuals (e.g., through a DNA barcoding approach). Unique status would be indicated if their DNA sequences are distinct from those of close relatives. Given that taxonomic expertise and funding are on the decline, we advocate considering such alternative approaches to describing species. A combination of ecological or other biodiversity surveys with large-scale DNA sequencing, as presented here (Dexter et al., 2010), offers the possibility of greatly increasing the rate of documentation of novel species (Janzen et al., 2005; Caesar et al., 2006). This could be particularly critical in tropical ecosystems, which face grave threats and where most undiscovered diversity lies (e.g., Hebert et al., 2004; Janzen et al., 2005).

Additional specimens examined. PERU. Madre de Dios: Centro de Monitoreo Los Amigos, 5 May 2006 (sterile), K. G. Dexter \& C. Lazo 1171 (DUKE); Cocha Cashu Biological Station, 1 July 2006 (sterile), K. G. Dexter \& C. Lazo 2992 (DUKE); Las Piedras Biodiversity Station, 3-5 Nov. 2006 (sterile), K. G. Dexter, E. Quispe \& J. C. Lara 3956 (DUKE), 3986 (DUKE), 3988 (DUKE), 4017 (K), 4071 (DUKE).

Acknowledgments. We thank Erin Tripp, Norm Douglas, and Mario Ruiz for reading and improving earlier drafts of this manuscript. We thank Tim Paine for suggesting the etymology and Rosemary Wise for illustrating Inga pitmanii. This work was funded by the National Science Foundation (NSF) grant (DDIG0608368) and grants from the Duke University Graduate School, Duke University Biology Department, Lewis and Clark Fund of the American Philosophical Society, Exploration Fund of the Explorer's Club, Sigma Xi, Society of Systematic Biologists, Caribbean and Latin American Studies Consortium, Amazon Conservation Association, and Organization for Tropical Studies to K.G.D. K.G.D. was supported by an NSF pre-doctoral fellowship during the time this work was completed. The authors also express gratitude to the Instituto Nacional para Recursos Naturales (INRENA) of Peru for permission to conduct fieldwork and to Fabiola Parra, Carlos Lazo, Edwin Quispe, and Juan Carlos Lara for field assistance.

\section{Literature Cited}

Caesar, R. M., M. Sorensson \& A. I. Cognato. 2006. Integrating DNA data and traditional taxonomy to streamline biodiversity assessment: An example from edaphic beetles in the Klamath ecoregion, California, U.S.A. Diversity \& Distrib. 12: 483-489.

Dexter, K. G. 2008. The Effects of Dispersal on Macroecological Patterns. Ph.D. Thesis, Duke University, Durham.

Dexter, K. G., T. D. Pennington \& C. W. Cunningham. 2010. Using DNA to assess errors in tropical tree identifications: How often are ecologists wrong and does it matter? Ecol. Monogr. 80: 267-286.

Hebert, P. D. N., E. H. Penton, J. M. Burns, D. H. Janzen \& W. Hallwachs. 2004. Ten species in one: DNA barcoding reveals cryptic species in the Neotropical skipper butterfly Astraptes fulgerator. Proc. Natl. Acad. Sci. U.S.A. 101: 14812-14817.

IUCN. 2001. IUCN Red List Categories and Criteria, Version 3.1. Prepared by the IUCN Species Survival Commission. IUCN, Gland, Switzerland, and Cambridge, United Kingdom.

Janzen, D. H., M. Hajibabaei, J. M. Burns, W. Hallwachs, E. Remigio \& P. D. N. Hebert. 2005. Wedding biodiversity inventory of a large and complex Lepidoptera fauna with DNA barcoding. Philos. Trans. Ser. B 360: 1835-1845.

Pennington, T. D. 1997. The Genus Inga: Botany. Royal Botanic Gardens, Kew, Richmond.

Pitman, N. C. A., J. Terborgh, M. R. Silman \& P. Nuñez. 1999. Tree species distributions in an upper Amazonian forest. Ecology 80: 2651-2661.

Terborgh, J. 1990. An overview of research at Cocha Cashu Biological Station. Pp. 48-59 in A. H. Gentry (editor), Four Neotropical Forests. Yale University Press, New Haven. 


\section{$2 \mathrm{BHL}$ Biodiversity Heritage Library}

Dexter, Kyle G and Pennington, T. D. 2011. "Inga pitmanii (Fabaceae), a New Species from Madre de Dios, Peru." Novon a journal of botanical nomenclature from the Missouri Botanical Garden 21(3), 322-325.

https://doi.org/10.3417/2009140.

View This Item Online: https://www.biodiversitylibrary.org/item/180102

DOI: https://doi.org/10.3417/2009140

Permalink: https://www.biodiversitylibrary.org/partpdf/218495

\section{Holding Institution}

Missouri Botanical Garden, Peter H. Raven Library

\section{Sponsored by}

Missouri Botanical Garden

\section{Copyright \& Reuse}

Copyright Status: Permission to digitize granted by rights holder

Rights: https://www.biodiversitylibrary.org/permissions

This document was created from content at the Biodiversity Heritage Library, the world's largest open access digital library for biodiversity literature and archives. Visit BHL at https://www.biodiversitylibrary.org. 